\title{
PENGARUH KEGIATAN PROMOSI TERHADAP PREFERENSI MAHASISWA DALAM MEMILIH UNIVERSITAS DEHASEN BENGKULU
}

\author{
Oleh:
}

\section{FERA INDA SARI}

\author{
Dosen Program Studi Ilmu Komunikasi Fakultas Ilmu-Ilmu Sosial \\ Universitas Dehasen Bengkulu
}

\begin{abstract}
This study aimed to analyze the effect of promotional activities on student preferences in choosing Dehasen University of Bengkulu on the assumption that a person chooses for their factors of rational choice inside. Variable influence of promotional activities are : $X_{1}$ (advertising), $X_{2}$ (personal selling), $X_{3}$ (Publicity), the control variables are $: Z_{1}$ (selective buying motives), $Z_{2}$ (patronage buying motives), $Z_{3}$ (primary buying motives), and variables affected $Y$ (Student preferences). The sample in this research were 245 peoples who are students at the University of Bengkulu Dehasen force from 2015 to 2016. The results of the study found that the ads are not able to influence the primary buying motives University Students Dehasen Bengkulu for prospective students consider one of the basic needs is education, so basically students who feel that education is a basic requirement will not see advertising as a reference, but the impact of fulfillment the study is due to have a proper education, students will have the ability in a variety of academic fields so that students will get a decent job and of the rewards of decent work in addition to the basic needs of education students will be able to be fulfilled optimum. Variable personal selling and publicity can influence selective buying motives, patronages buying motives, and the primary buying motives, but patronage buying motives has no influence on the preference of the student so that it can be concluded that personal selling and publicity will be able to influence the preferences of students by influencing selective buying motives and Pimary buying motives first.
\end{abstract}

\section{Keywords : Promotion Activities, The Rational Choice, Preference}

\section{PENDAHULUAN}

Salah satu perusahaan jasa yang keberadaannya sangat dibutuhkan oleh masyarakat saat ini adalah perguruan tinggi swasta, mengingat jumlah penduduk di Indonesia yang begitu besar yaitu 255.461.700 jiwa atau 3,48\% penduduk dunia dan merupakan penduduk dengan jumlah terbesar nomor empat di dunia (Wikipedia, di downlad pada tanggal 8 Agustus 2016) sehingga sudah dapat ipastikan bahwa perguruan tinggi negeri yang ada di Indonesia tidak akan cukup untuk memenuhi kebutuhan pendidikan.

Universitas Dehasen Bengkulu merupakan lembaga pendidikan swasta yang didirikan oleh Bando Amin C. Kader dan merupakan universitas swasta yang cukup baik di Provinsi Bengkulu, mengingat banyaknya calon mahasiswa yang berminat untuk melanjutkan pendidikan di Universitas tersebut. Universitas Dehasen Bengkulu memiliki kegiatan untuk melayani konsumen berupa mahasiswa. Lembaga pendidikan Universitas Dehasen bengkulu pada hakikatnya bertujuan untuk memberikan layanan dan pihak yang dilayani ingin memperoleh kepuasan dari layanan pendidikan yang diberikan, karena mereka sudah membayar cukup mahal kepada 
Universitas Dehasen Bengkulu dengan harapan memperoleh pendidikan yang baik dan bermanfaat bagi kehidupan mahasiswa setelah menyelesaikan studi pada Universitas Dehasen Bengkulu.

Jumlah mahasiswa merupakan unsur terpenting dalam kemajuan dan perkembangan yang signifikan terhadap Universitas Dehasen Kota Bengkulu, peningkatan jumlah mahasiwa sangatlah penting dikarenakan berbagai kasus perguruan tinggi yang tidak mampu menjalankan tujuannya akibat dari tidak bertambahnya jumlah mahasiswa dan akhirnya terpaksa ditutup. Jumlah mahasiswa yang sesuai dengan harapan bukan hanya dapat membantu perguruan tinggi untuk tetap mendapat keuntungan akan tetapi dengan jumlah mahasiswa yang signifikan maka Universitas Dehasen Kota Bengkulu akan mampu memberikan kontribusi efektif akan kebutuhan pendidikan masyarakat, dan hal ini tentu akan meningkatkan kualitas civitas akademik secara keseluruhan.

Sebagai lembaga pendidikan maka Universitas Dehasen Bengkulu memusatkan untuk memperoleh keuntungan dan keuntungan tersebut diperuntukkan untuk meningkatkan mutu layanan kepada mahasiswa ataupun calon mahasiswa dalam upaya peningkatan jumlah calon mahasiswa yang berminat mendaftarkan diri di Universitas Dehasen Bengkulu maupun mempertahankan mahasiswa yang ada pada Universitas Dehasen Bengkulu tersebut. Dalam pencapaian tujuan sebagai lembaga pendidikan yang sukses di masa depan dan memiliki citra yang baik karena merupakan pilihan yang tepat untuk melanjutkan studi perguruan tinggi yang dianggap baik oleh masyarakat maka Universitas Dehasen bengkulu haruslah mampu untuk menghadapi persaingan tersebut dan melakukan tindakan nyata dengan melakukan kegiatan promosi sebagai tindakan komunikasi untuk menyebarluaskan keunggulan Universitas Dehasen bengkulu agar dapat menarik minat calon mahasiswa untuk berkuliah pada Universitas Dehasen Bengkulu.

Tindakan promosi yang dilakukan oleh Universitas Dehasen Kota Bengkulu, disinyalir merupakan sebuah tindakan yang efektif untuk dilakukan mengingat ketatnya persaingan antar perguruan tinggi swasta yang ada di Kota Bengkulu, maka dari itu dengan adanya promosi Universitas Dehasen berharap bahwa Universitas Dehasen Kota bengkulu akan dapat dikenal secara luas oleh masyarakat dan menjadi salah satu pilihan yang tepat untuk melanjutkan pendidikan pada tingkatan perguruan tinggi

Menurut Hermawan (2012:38), kegiatan promosi merupakan salah satu komponen yang menjadi prioritas dari kegiatan pemasaran. Dengan adanya promosi maka konsumen akan mengetahui bahwa perusahaan meluncurkan produk baru yang akan menggoda konsumen untuk melakukan kegiatan pembelian. Berdasarkan pengertian dari Hermawan tersebut maka sudah selayaknya tindakan promosi dilaksanakan untuk memperlancar pencapaian tujuan yang ditetapkan oleh Universitas Dehasen yaitu memperoleh mahasiswa sebanyak-banyaknya.

Dalam pelaksanaannya yang menjadi permasalahan paling krusial yang dialami oleh setiap perguruan tinggi swasta adalah mengatasi persaingan yang sangat ketat antar perguruan swasta lainnya, persaingan yang ada bukan hanya di dalam Kota Bengkulu saja akan tetapi persaingan sudah sangat luas dikarenakan informasi yang sangat mudah untuk dijelajahi di era modren ini.

Seluruh perguruan tinggi swasta bahkan perguruan tinggi negeripun melakukan kegiatan promosi, dikarenakan masyarakat akan disuguhkan banyak pilihan perguruan tinggi yang memiliki berbagai kelebihannya masing-masing sehingga masyarakat menjadi lebih selektif dalam memilih, maka dari itu Universitas Dehasen bengkulu harus lebih gencar melakukan tindakan promosi dan menarik perhatian khalayak dengan memberikan 
penjelasan yang menarik mengenai kelebihan-kelebihan Universitas Dehasen bengkulu.

Perlu diingat bahwa persaingan antar perguruan tinggi swasta di Bengkulu cukup signifikan dan perlu mendapatkan perhatian khusus bagi Universitas Dehasen, agar tidak dapat menyaingi kompetitor dan tetap mempertahankan eksistensi Universitas Dehasen sebagai perguruan tinggi pilihan bagi masyarakat di Provinsi Bengkulu mengingat pada Provinsi Bengkulu terdapat 5 (lima) perguruan tinggi swasta yang telah dikenal secara luas oleh masyarakat Bengkulu dengan berbagai kelebihannya masingmasing, adapun universitas swasta tersebut adalah : Universitas Muhamadiyah Bengkulu (UMB), Universitas Hazairin (UNIHAZ), Sekolah Tinggi Ilmu administrasi (STIA), Universitas Ratu Samban (UNRAS), dan Universitas Dehasen (UNIVED), kelima perguruan tinggi swasta tersebut memiliki persaingan yang sangat ketat dalam menjaring mahasiswa baru demi keberlangsungan kegiatan pendidikan yang sudah dijalankan masing-masing perguruan tinggi swasta tersebut. mengingat banyaknya pesaing maka Universitas Dehasen haruslah lebih jeli mencari peluang dalam menjalankan kegiatan promosinya agar dapat secara efektif meningkatkan preferensi masyarakat dalam memilih Universitas Dehasen sebagai wadah pendidikan yang layak. Kegiatan promosi pada Universitas Dehasen Bengkulu akan memiliki pengaruh yang tinggi terhadap peningkatan jumlah mahasiswa Universitas Dehasen Bengkulu.

Selain periklanan menurut Hermawan adapun faktor yang menjadikan tindakan promosi yang dapat mempengaruhi preferensi seseorang dalam menetapkan pilihannya pada perguruan tinggi tertentu sebagai wadah untuk menuntut ilmu dalam (Hermawan, 2012:38) yang tepat adalah: Program periklanan, Promosi personal selling.
Sales promotion/ additional values product, Publisitas.

Dari keempat komponen yang telah disebutkan maka diketahui ada beberapa komponen yang benar-benar memungkinkan untuk dilakukan oleh Universitas Dehasen bengkulu dalam upaya mencapai peningkatan jumlah mahasiswa setiap tahunnya, selain iklan adapun beberapa kegiatan promosi lainnya yang dilakukan oleh Universitas Dehasen adalah personal selling, dan publisitas sedangkan sales promotion tidak dimungkinkan untuk dilaksanakan oleh Universitas Dehasen Bengkulu karena dianggap tidak efektif untuk menyediakan tim untuk berkeliling dan memiliki standstand khusus untuk mempromosikan Universitas Dehasen bengkulu mengingat yang dipromosikan adalah jasa pendidikan sehingga apabila menggunakan sales promotion digunakan dalam kegiatan promosi maka Universitas Dehasen Bengkulu akan terkesan tidak kredibel dan hanya memerlukan mahasiswa saja tanpa memikirkan kualitas dari calon mahasiswa tersebut.

Berdasarkan observasi pra penelitian diketahui bahwa Universitas Dehasen telah menjalankan program periklanan dengan baik dan berkala, ini dilakukan dengan menggunakan beberapa media periklanan, dimana media perikalanan yang digunakan oleh Universitas Dehasen adalah dengan menggunakan televisi, radio, surat kabar, dan media luar ruang akan tetapi pada kenyataannya kegiatan perikalanan tersebut belum dapat meningkatkan jumlah mahasiswa secara signifikan, ini dilihat dari data penerimaan mahasiswa baru yang tidak stabil atau naik turun tiap tahunnya.

Adapun target dan jumlah mahasiswa yang diterima setiap tahunnya pada 5 tahun terakhir dapat dilihat pada tabel berikut: 
Tabel 1. Jumlah Mahasiswa Baru Universitas Dehasen Bengkulu TA. 2011/2012-TA.2015/2016

\begin{tabular}{|c|c|c|}
\hline $\begin{array}{c}\text { Tahun } \\
\text { Ajaran }\end{array}$ & $\begin{array}{c}\text { Calon } \\
\text { Pendaftar }\end{array}$ & $\begin{array}{c}\text { Jumlah } \\
\text { Mahasiswa } \\
\text { Baru }\end{array}$ \\
\hline $2011 / 2012$ & 1310 & 1233 \\
$2012 / 2013$ & 1101 & 1051 \\
$2013 / 2014$ & 1100 & 1067 \\
$2014 / 2015$ & 1101 & 1050 \\
$2015 / 2016$ & 1300 & 1216 \\
\hline
\end{tabular}

Sumber : BAAK Unived Tahun 2016

Jumlah Fakultas di Universitas Dehasen Bengkulu adalah 8, diantaranya adalah Fakultas Ilmu Komputer, Fakultas Ekonomi, Fakultas Ilmu Sosial, Fakultas Pertanian, Fakultas Tehnik, Fakultas Keguruan dan Ilmu Pendidikan dan Fakultas Hukum. Berdasarkan tabel 1 tersebut maka diketahui bahwa jumlah mahasiswa yang masuk setiap tahunnya tidak stabil atau naik turun sedangkan kegiatan promosi telah dilakukan secara berkala. Oleh karena itu tindakan untuk mengetahui sejauh mana kegiatan promosi efektif dalam membentuk preferensi mahasiswa ataupun calon mahasiswa haruslah dianalisis guna menjelaskan kepada masyarakat mengenai kompetensi serta keunggulan produk yang ditawarkan oleh Universitas Dehasen Bengkulu.

Dari kelima perguruan tinggi yang ada di Provinsi Bengkulu maka berdasarkan observasi yang dilakukan diketahui Universitas Dehasen memiliki 2 pesaing terberat yaitu Universitas Hazairin Bengkulu dan Universitas Muhamadiyah Bengkulu, kedua Universitas tersebut merupakan Universitas yang memiliki jumlah intensitas peminat yang cukup tinggi pada Provinsi Bengkulu, dengan jumlah mahasiswa yang diterima angkatan 2015/2016 pada Universitas Hazairin adalah 1115 orang mahasiswa, dan jumlah mahasiswa yang terdaftar pada Universitas Muhamadiyah Bengkulu adalah sebesar 2787 orang mahasiswa. Ini membuktikan bahwa Universitas Dehasen masih belum mampu bersaing dengan baik meskipun
Universitas Dehasen telah melakukan berbagai kegiatan promosi, akan tetapi universitas Dehasen sejauh ini telah berkembang sangat pesat mengingat Universitas Dehasen tergolong Universitas yang baru sedangkan UMB dan UNIHAZ telah menjadi universitas senior di Kota Bengkulu.

Universitas Hazairin dan Universitas Muhamadiyah Bengkulu merupakan kompetitor sebagai Universitas yang sudah memiliki nama baik dan memiliki reputasi yang baik di mata masyarakat Bengkulu dan kedua perguruan tinggi tersebut diketahui sama gencarnya melakukan kegiatan periklanan untuk terus mencapai tujuan memenuhi kuota mahasiswanya, sehingga tidaklah cukup bagi Universitas Dehasen untuk hanya melakukan tindakan periklanan saja tanpa ada kegiatan promosi lainnya yang menunjang kekuatan Universitas untuk mendapatkan mahasiswa sebanyak-banyaknya.

Preferensi berasal dari kata Preference mempunyai makna pilihan atau memilih. Istilah preferensi digunakan untuk mengganti kata preference dengan arti yang sama atau minat terhadap sesuatu. Preferensi merupakan suatu sifat atau keinginan untuk memilih. (Journal Planit: 2001). Menurut Doris Grober preferensi media umunya meminta pengguna media untuk mengurutkan preferensi pengguna terhadap suatu media (Vivian, 2010: 567).

$$
\text { Menurut Indarto }
$$

Preferensi konsumen didefinisikan sebagai selera subjektif (individu), yang diukur dengan utilitas, dari bundel berbagai barang. Konsumen dipersilahkan untuk melakukan rangking terhadap bundel barang yang mereka berikan pada konsumen. Dalam permasalahan penelitian produk yang ditawarkan oleh Universitas Dehasen Bengkulu adalah produk jasa pendidikan, sehingga universitas Dehasen Bengkulu haruslah memasukkan unsurunsur kualitas yang baik dalam kegiatan promosinya calon mahasiswa maupun mahasiwa Universitas Dehasen bengkulu 
akan menentukan menentukan preferensi mereka terhadap Universitas Dehasen bengkulu.

Untuk mengetahui faktor preferensi mahasiswa setelah menerima kegiatan promosi yang dilakukan oleh Universitas Dehasen Bengkulu dalam menjadikan Universitas Dehasen bengkulu menjadi sebuah pilihan yang tepat maka penelitian akan dilakukan dengan mengaitkannya dengan teori pilihan rasional, karena diasumsikan pada dasarnya bahwa seorang mahasiswa yang telah menetapkan pilihannya pada Universitas Dehasen diliputi oleh pertimbangan-pertimbangan yang menurut mahasiswa masuk akal dan mampu memenuhi keinginan mahasiswa secara rasional.

Dennis Kavanaagh dalam Surbakti (1992:146) menyatakan bahwa pilihan rasional melihat kegiatan perilaku memilih sebagai produk kalkulasi antara untung dan rugi. Ini disebabkan karena pemilih tidak hanya mempertimbangkan ongkos memilih dan kemungkinan pilihannya dapat mempengaruhi hasil yang diharapkan, tetapi juga perbedaan dari alternatif-alternatif berupa pilihan yang ada. Calon mahasiswa dalam penelitian ini diasumsikan memiliki motivasi, prinsip, pendidikan, pengetahuan, dan informasi yang cukup. Berdasarkan informasi, pendidikan dan pengetahuan yang dimiliki calon mahasiswa memutuskan harus menentukan pilihannya dengan pertimbangan untung dan ruginya untuk menetapkan pilihan atas alternatifalternatif yang ada kepada pilihan yang terbaik dan yang paling menguntungkan baik untuk kepentingan sendiri (self interest) maupun untuk kepentingan umum disekitar calon mahasiswa tersebut.

Setelah mahasiswa menerima kegiatan promosi yang dilakukan oleh Universitas Dehasen Bengkulu maka mahasiswa selaku seseorang yang memilih Universitas Dehasen bengkulu menjadi perguruan tinggi yang tepat untuk melanjutkan pendidikannya memiliki beberapa motif yang melatarbelakanginya sehingga pilihannya tersebut dianggap rasional dan benar-benar telah sesuai dengan apa yang menjadi tujuan mahasiswa, adapun menurut Buchari (2011:97) ada 3 motif penting yang menjadi alasan dalam melatarbelakangi mahasiswa menentukan pilihannya diantaranya adalah : Selective buying motive, yaitu pemilihan terhadap produk ini berdasarkan ratio misalnya, apakah ada keuntungan ketika memilih Universitas Dehasen Bengkulu sebagai wadah melanjutkan kegiatan pendidikan yang tepat. Berdasarkan waktu seperti mahasiswa akan mampu menjalankan pendidikan tepat waktu. Berdasarkan emosi, seperti melanjutkan pendidikan karena mengikuti teman. Jadi Selective dapat berbentuk Rational Buying Motive, emotional buying motive atau Impulse (dorongan seketika), patronage buying motive, selective buying motive yang ditujukan kepada Universitas Dehasennya sendiri. Pemilihan ini bisa timbul karena layanan memuaskan, tempatnya dekat, cukup persediaan barang, ada halaman parkir, primary buying motive, yaitu motif untuk membeli yang sebenamya misalnya, ketika mahasiswa hanya memiliki tujuan untuk berkuliah tanpa dipengaruhi faktor lain.

Dengan memperhatikan semua yang penulis sebutkan tersebut, maka hal yang perlu dianalisis adalah "Pengaruh Kegiatan Promosi terhadap preferensi mahasiswa dalam memilih universitas Dehasen Bengkulu".

\section{METODE PENELITIAN}

Penelitian ini merupakan penelitian yang besifat deskriptif kuantitatif, dimana penelitian ini dilakukan dengan menganalisis data-data berupa angkaangka yang dikumpulkan dan disusun serta diolah untuk menjelaskan sebuah gambaran mengenai suatu permasalahan.

Metode pengambilan sampel dalam penelitian ini adalah dengan menggunakan rumus yang dikembangkan oleh Arikunto (2002:116) dimana untuk menentukan 
besarnya sampel apabila subjek kurang dari 100, lebih baik diambil semua sehingga penelitiannya penelitian populasi. Jika subjeknya lebih besar dapat diambil antara 20-25\%, maka diketahui jumlah sampel yang diambil dalam penelitian ini adalah sebanyak 245 mahasiswa pada Universitas Dehasen Bengkulu, adapun cara menentukan sampel dalam penelitian ini adalah random sampling yaitu teknik pengambilan sampel dimana semua individu dalam populasi baik secara sendiri-sendiri atau bersama-sama diberi kesempatan yang sama untuk dipilih sebagai anggota sampel (Sugiyono, 2010:340), jenis skala dalam penelitian ini adalah skala ordinal adapun yang dimaksud dengan skala ordinal adalah menurut Ritonga (2007:15) skala yang menggunakan logika untuk membuat kategori-kategori”.

Penelitian ini menggunakan skala likert sebagai skala pengukurannya, dimana Sugiyono (2010:93) mengatakan bahwa skala likert adalah skala yang digunakan untuk mengukur sikap, pendapat, dan persepsi seseorang atau sekelompok orang tentang fenomena sosial. Menurut Nicholas Walliman dalam Silalahi (2015:339) skala interval memiliki skor yang seimbang, ini berarti antara nilai yang satu dengan yang lainnya terdapat selisih yang dapat dihitung dan dinyatakan dalam angka, jarak yang sama pada skala interval dipandang sebagai mewakili jarak yang sama pula pada objek yang diukur.

Berikut adalah tabel yang menunjukkan bobot dari masing-masing kategori penilaian tersebut menurut Sugiyono (2010:93) :

Tabel 2. Skala Pengukuran Kuesioner berdasarkan intervalnya

\begin{tabular}{|c|c|c|c|}
\hline No & $\begin{array}{c}\text { Alternatif } \\
\text { Jawaban }\end{array}$ & Akronim & $\begin{array}{c}\text { Skor } \\
\text { Nilai }\end{array}$ \\
\hline 1 & Sangat Setuju & SS & 5 \\
\hline 2 & Setuju & S & 4 \\
\hline 3 & Cukup setuju & CS & 3 \\
\hline 4 & Tidak setuju & TS & 2 \\
\hline 5 & $\begin{array}{c}\text { Sangat tidak } \\
\text { setuju }\end{array}$ & STS & 1 \\
\hline
\end{tabular}

Analisis yang dgunakan dalam penelitian ini adalah Analisis path, Merujuk pendapat yang dikemukakan oleh Land, Ching, Heise, Maruyama, Schumaker dan Lomax, Joreskog (dalam Kusnendi, 2008:147-148), karakteristik analisis jalur adalah metode analisis data multivariat dependensi yang digunakan untuk menguji hipotesis hubungan asimetris yang dibangun atas dasar kajian teori tertentu, dengan tujuan untuk mengetahui pengaruh langsung dan tidak langsung seperangkat variabel penyebab terhadap variabel akibat.Menguji hipotesis hubungan asimetris yang dibangun atas kajian teori tertentu artinya yang diuji adalah model yang menjelaskan hubungan kausal antarvariabel yang dibangun atas kajian teori teori tertentu. Hubungan kausal tersebut secara eksplisit dirumuskan dalam bentuk hipotesis direksional, baik positif maupun negative.

Uji t digunakan untuk rnengetahui secara parsial pengaruh masing-masing variabel bebas terhadap variabel terikat, dengan asurnsi bahwa: Jika $\mathrm{P}$ value $<\alpha$, maka Ho ditolak, dan Ha diterima, Uji $F$ digunakan untuk menguji secara bersamaan. Uji hipotesis penelitian pertama ini digunakan untuk mengetahui secara bersama-sarma, pengaruh variabelvanabel bebas terhadap variabel terikat, dengan asumsi bahwa: Jika $\mathrm{P}$ value $<\alpha$, maka Ho ditolak, dan Ha diterima.

\section{HASIL DAN PEMBAHASAN}

Berdasarkan penelitian yang dilakukan maka diketahui hasil sebagai berikut :

Pengaruh Iklan (X1), Personal Selling $\left(\mathbf{X}_{2}\right)$, dan Publisitas (X) Terhadap Selective Buying Motives (Z1)

Berdasarkan hasil analisis maka diketahui bahwa nilai $\mathrm{R}^{2}=0,948$ artinya, secara simultan variabel $\mathrm{X}_{1}, \mathrm{X}_{2}, \mathrm{X}_{3}$ memiliki kontribusi sebesar $94,8 \%$ dalam menjelaskan perubahan yang terjadi pada variable $Z_{1}$, sedangkan sisanya sebesar 
$5,2 \%$ dijelaskan oleh variabel lain di luar model.

Pada bagian Anova (Uji F) terlihat bahwa secara simultan variabel $\mathrm{X}_{1}, \mathrm{X}_{2}, \mathrm{X}_{3}$ memiliki pengaruh terhadap variabel $\mathrm{Z}_{1}$ yang ditunjukkan dari nilai sig. 0,000 atau lebih kecil daripada 5\% artinya hipotesis alternatif diterima.

Pada bagian coefficient, uji t/parsial terlihat bahwa variabel $\mathrm{X}_{2}, \mathrm{X}_{3}$ secara statistic memiliki pengaruh yang signifikan terhadap variabel $\mathrm{Z}_{1}$ yang ditunjukkan oleh nilai sig. masing-masing lebih kecil dari alpha 5\% yaitu 0,000 untuk $\mathrm{X}_{1}, \quad 0,000$ untuk $\mathrm{X}_{2}$ dan $0,000 \quad \mathrm{X}_{3}$. Persamaan strukturalnya menjadi seperti berikut : $\mathrm{Z} 1=0,390 \mathrm{X}_{1}+0,371 \mathrm{X}_{2}+$ $0,261 X_{3}+\epsilon_{1}$. Dari tanda nilai koefisien (+), maka diketahui bahwa variabel iklan $\left(\mathrm{X}_{1}\right)$, personal selling $\left(\mathrm{X}_{2}\right)$, dan Publisitas $\left(\mathrm{X}_{3}\right)$ memiliki pengaruh yang positif terhadap selective buying motives $\left(\mathrm{Z}_{1}\right)$, interpretasi variabel $\mathrm{X}_{1}=$ peningkatan sebesar 1 satuan variabel $X_{1}$ akan meningkatkan variabel $Z_{1}$ sebesar 0,390 satuan dengan asumsi variabel bebas lain dianggap konstan artinya, hipotesis diterima. Interpretasi variabel $\mathrm{X}_{2}=$ peningkatan sebesar 1 satuan variabel $\mathrm{X}_{2}$ akan meningkatkan variabel $\mathrm{Z}_{1}$ sebesar 0,371 satuan dengan asumsi variabel bebas lain dianggap konstan artinya, hipotesis diterima. Interpretasi variabel $\mathrm{X}_{3}=$ peningkatan sebesar 1 satuan variabel $X_{3}$ akan meningkatkan variabel $\mathrm{Z}_{1}$ sebesar 0,261 satuan dengan asumsi variabel bebas lain dianggap konstan artinya, hipotesis diterima.

\section{Pengaruh Iklan (X1), Personal Selling $\left(\mathbf{X}_{2}\right)$, Dan Publisitas $\left(\mathbf{X}_{3}\right)$ Terhadap Patronage Buying Motives $\left(\mathrm{Z}_{2}\right)$}

Berdasarkan hasil analisis maka diketahui bahwa nilai $\mathrm{R}^{2}=0,834$ artinya, secara simultan variabel $\mathrm{X}_{1}, \mathrm{X}_{2}, \mathrm{X}_{3}$ memiliki kontribusi sebesar $83,4 \%$ dalam menjelaskan perubahan yang terjadi pada variable $Z_{2}$, sedangkan sisanya sebesar $16,6 \%$ dijelaskan oleh variabel lain di luar model.
Pada bagian Anova (Uji F) terlihat bahwa secara simultan variabel $\mathrm{X}_{1}, \mathrm{X}_{2}, \mathrm{X}_{3}$ memiliki pengaruh terhadap variabel $\mathrm{Z}_{2}$ yang ditunjukkan dari nilai sig. 0,000 atau lebih kecil daripada 5\% artinya hipotesis alternative diterima.

Pada bagian coefficient, uji t/parsial terlihat bahwa variabel $\mathrm{X}_{1}, \mathrm{X}_{2}, \mathrm{X}_{3}$, secara statistic memiliki pengaruh yang signifikan terhadap variabel $Z_{2}$ yang ditunjukkan oleh nilai sig. masing-masing lebih kecil dari alpha 5\% yaitu 0,000 untuk $\mathrm{X}_{1}, 0,000$ untuk $\mathrm{X}_{2}$ dan $0,000 \mathrm{X}_{3}$.

Persamaan strukturalnya menjadi seperti berikut: $\mathrm{Z}_{2}=0,435 \mathrm{X}_{1}+0,308 \mathrm{X}_{2}+$ $0,237 X_{3}+\epsilon_{2}$, Dari tanda nilai koefisien $(+)$, maka diketahui bahwa variabel iklan $\left(\mathrm{X}_{1}\right)$, personal selling $\left(\mathrm{X}_{2}\right)$, dan Publisitas $\left(\mathrm{X}_{3}\right)$ memiliki pengaruh yang positif terhadap patronage buying motives $\left(\mathrm{Z}_{2}\right)$. Interpretasi variabel $\mathrm{X}_{1}=$ peningkatan sebesar 1 satuan variabel $\mathrm{X}_{1}$ akan meningkatkan variabel $\mathrm{Z}_{2}$ sebesar 0,435 satuan dengan asumsi variabel bebas lain dianggap konstan artinya, hipotesis diterima, Interpretasi variabel $\mathrm{X}_{2}=$ peningkatan sebesar 1 satuan variabel $\mathrm{X}_{2}$ akan meningkatkan variabel $\mathrm{Z}_{2}$ sebesar 0,308 satuan dengan asumsi variabel bebas lain dianggap konstan artinya, hipotesis diterima, dan Interpretasi variabel $\mathrm{X}_{3}=$ peningkatan sebesar 1 satuan variabel $\mathrm{X}_{3}$ akan meningkatkan variabel $\mathrm{Z}_{2}$ sebesar 0,237 satuan dengan asumsi variabel bebas lain dianggap konstan artinya, hipotesis diterima.

Pengaruh Iklan $\left(\mathrm{X}_{1}\right)$, Personal Selling $\left(\mathbf{X}_{2}\right)$, Dan Publisitas ( $\left.\mathbf{X}_{3}\right)$ Terhadap Primary Buying Motives $\left(\mathrm{Z}_{3}\right)$

Berdasarkan hasil analisis maka diketahui bahwa nilai $\mathrm{R}^{2}=0,595$ artinya, secara simultan variabel $\mathrm{X}_{1}, \mathrm{X}_{2}, \mathrm{X}_{3}$ memiliki kontribusi sebesar 59,5\% dalam menjelaskan perubahan yang terjadi pada variable $Z_{3}$, sedangkan sisanya sebesar $40,5 \%$ dijelaskan oleh variabel lain di luar model.

Pada bagian Anova (Uji F) terlihat bahwa secara simultan variabel $\mathrm{X}_{1}, \mathrm{X}_{2}, \mathrm{X}_{3}$ memiliki pengaruh terhadap variabel 
$Z_{3}$ yang ditunjukkan dari nilai sig. 0,000 atau lebih kecil daripada 5\% artinya hipotesis alternatif diterima.

Pada bagian coefficient, uji t/parsial terlihat bahwa variabel $\mathrm{X}_{2}, \mathrm{X}_{3}$, secara statistik memiliki pengaruh yang signifikan terhadap variabel $\mathrm{Z}_{3}$ yang ditunjukkan oleh nilai sig. masing-masing lebih kecil dari alpha 5\% yaitu 0,000 untuk $\mathrm{X}_{2}$ dan $0,000 \mathrm{X}_{3}$, variabel $\mathrm{X}_{1}$ secara parsial tidak signifikan mempengaruhi variabel $\mathrm{Z}_{3}$, yang terlihat dari nilai sig. sebesar $0,243>5 \%$ sehingga variabel $X_{1}$ di eliminasi dari model pengaruh iklan $\left(\mathrm{X}_{1}\right)$, personal selling $\left(\mathrm{X}_{2}\right)$, dan Publisitas $\left(\mathrm{X}_{3}\right)$ terhadap primary buying motives $\left(\mathrm{Z}_{3}\right)$.

Persamaan strukturalnya menjadi seperti berikut : $Z_{3}=0,473 X_{2}+0,379 X_{3}+$ $\epsilon_{3}$. Dari tanda nilai koefisien $(+)$, maka diketahui bahwa variabel personal selling $\left(\mathrm{X}_{2}\right)$, dan Publisitas $\left(\mathrm{X}_{3}\right)$ memiliki pengaruh yang positif terhadap patronage buying motives $\left(\mathrm{Z}_{3}\right)$ : Interpretasi variabel $\mathrm{X}_{1}=$ tidak ada pengaruh $\mathrm{X}_{1}$ terhadap $\mathrm{Z}_{3}$ artinya hipotesis ditolak, interpretasi variabel $\mathrm{X}_{2}=$ peningkatan sebesar 1 satuan variabel $\mathrm{X}_{2}$ akan meningkatkan variabel $\mathrm{Z}_{3}$ sebesar 0,473 satuan dengan asumsi variabel bebas lain dianggap konstan artinya, hipotesis diterima dan interpretasi variabel $X_{3}=$ peningkatan sebesar 1 satuan variabel $\mathrm{X}_{3}$ akan meningkatkan variabel $\mathrm{Z}_{3}$ sebesar 0,379 satuan dengan asumsi variabel bebas lain dianggap konstan artinya, hipotesis diterima.

Pengaruh Selective Buying Motives $\left(\mathrm{Z}_{1}\right)$, Dan Patronage Buying Motives $\left(\mathrm{Z}_{2}\right)$, Primary Buying Motives $\left(\mathrm{Z}_{3}\right)$ Terhadap Preferensi Mahasiswa (Y).

Berdasarkan gambar diatas maka diketahui bahwa nilai $\mathrm{R}^{2}=0,656$ artinya, secara simultan variabel $\mathrm{Z}_{1}, \mathrm{Z}_{2}, \mathrm{Z}_{3}$ memiliki kontribusi sebesar $65,6 \%$ dalam menjelaskan perubahan yang terjadi pada variable $\mathrm{Y}$, sedangkan sisanya sebesar $34,4 \%$ dijelaskan oleh variabel lain di luar model.
Pada bagian Anova (Uji F) terlihat bahwa secara simultan variabel $\mathrm{Z}_{1}, \mathrm{Z}_{2}, \mathrm{Z}_{3}$ memiliki pengaruh terhadap variabel Yyang ditunjukkan dari nilai sig. 0,000 atau lebih kecil daripada 5\% artinya hipotesis alternatif diterima.

Pada bagian coefficient, uji t/parsial terlihat bahwa variabel $\mathrm{Z}_{1}, \mathrm{Z}_{3}$, secara statistik memiliki pengaruh yang signifikan terhadap variabel $\mathrm{Y}$ yang ditunjukkan oleh nilai sig. masing-masing lebih kecil dari alpha 5\% yaitu 0,000 untuk $\mathrm{X}_{2}$ dan $0,000 \mathrm{X}_{3}$, variabel $\mathrm{Z}_{2}$ secara parsial tidak signifikan mempengaruhi variabel $\mathrm{Y}$, yang terlihat dari nilai sig. sebesar $0,305>5 \%$ sehingga variabel $Z_{2}$ di eliminasi dari model pengaruh selective buying motives $\left(\mathrm{Z}_{1}\right)$, dan patronage buying motives $\left(\mathrm{Z}_{2}\right)$,primary buying motives $\left(\mathrm{Z}_{3}\right)$ terhadap preferensi mahasiswa (Y).

Persamaan strukturalnya menjadi seperti berikut : $Z_{3}=0,487 Z_{1}+$ $0,028 Z_{2}+0,251 Z_{3}+\epsilon_{3}$. Dari tanda nilai koefisien (+), maka diketahui bahwa variabel selective buying motives $\left(\mathrm{Z}_{1}\right)$, dan primary buying motives $\left(\mathrm{Z}_{3}\right)$ memiliki pengaruh yang positif terhadap preferensi mahasiswa dengan asumsi sebagai berikut : Interpretasi variabel $\mathrm{Z}_{1}=$ peningkatan sebesar 1 satuan variabel $\mathrm{Z}_{1}$ akan meningkatkan variabel Ysebesar 0,581 satuan dengan asumsi variabel bebas lain dianggap konstan artinya, hipotesis diterima, interpretasi variabel $\mathrm{Z}_{2}=$ tidak ada pengaruh $\mathrm{Z}_{2}$ terhadap $\mathrm{Y}$ artinya hipotesis ditolak dan interpretasi variabel $\mathrm{Z}_{3}=$ peningkatan sebesar 1 satuan variabel $Z_{3}$ akan meningkatkan variabel Ysebesar 0,251 satuan dengan asumsi variabel bebas lain dianggap konstan artinya, hipotesis diterima.

Dari analisis path yang dilakukan maka dapat digambarkan model sebagai berikut : 


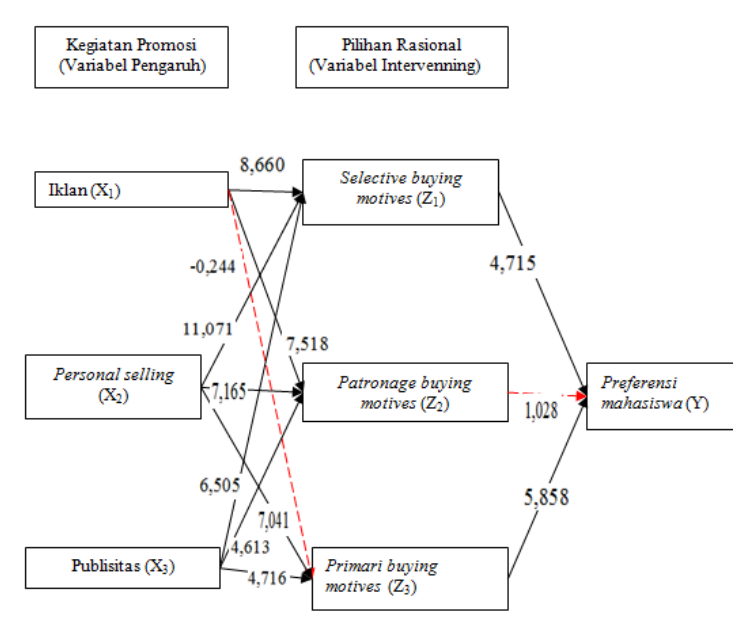

Gambar 1. Model analisis Path

Universitas Dehasen bengkulu menjadikan kegiatan promosi sebagai salah satu komponen yang menjadi prioritas dari kegiatan pemasarannya, dengan adanya promosi maka calon mahasiswa baru akan mengetahui mengenai Universitas Dehasen bengkulu. adapun kegiatan promosi yang secara rutin dilakukan oleh Universitas Dehasen bengkulu untuk membagi informasi mengenai hal positif Universitas Dehasen bengkulu adalah iklan, personal selling, dan publisitas.

Dari hasil analisis yang telah dilakukan diketahui kegiatan promosi tidak langsung mampu dalam mempengaruhi preferensi mahasiswa Universitas Dehasen Bengkulu. Ini dikarenakan adanya pilihan rasional dalam diri mahasiswa ketika hendak memtuskan untuk memilih Universitas Dehasen sebagai wadah melanjutkan pendidikan ke jenjang perguruan tinggi, mahasiswa mengakui bahwa kecendrungan untuk berfikir secara rasional sebelum memutuskan hendak melakukan sesuatu begitu pula dalam memutuskan untuk melanjutkan kuliah pada Universitas Dehasen. Mahasiswa akan memutuskan untuk melanjutkan kuliah pada Universitas Dehasen atau universitas lainnya dengan pemahaman rasional dalam diri mereka.

Pada dasarnya pilihan rasional dari mahasiswa Universitas Dehasen bengkulu merupakan sudut pandang atau optimasisasi yang mengungkapkan bahwa pilihan dipandang sebagai proses optimasisasi dalam memutuskan untuk memiliki preferensi terhadap Universitas Dehasen Bengkulu sebagai lembaga yang sesuai untuk melanjutkan pendidikan ditingkat perguruan tinggi swasta dalam Kota bengkulu.

Menurut Ritzr dan Smart (2015:546) mengatakan bahwa rasionalitas itu terbatas, dalam artian bahwa pengambil keputusan dianggap memiliki informasi terbatas dengan kesahian yang tidak menentu, serta kemampuan-kemampuan terbatas untuk memperoleh dan mengolah informasi. Berdasarkan teori tersebut dapat dilihat bahwa rasionalitas mahasiswa Universitas Dehasen bengkulu dalam penelitian ini dibatasi oleh perolehan informasi oleh mahasiswa dari kegiatan promosi yang dilakukan oleh Universitas Dehasen bengkulu sehingga calon mahasiswa dapat dikatakan akan memulai untuk berfikir rasional untuk mempertimbangkan keputusan dalam memilih Universitas Dehasen bengkulu ketika menerima informasi yang diperoleh dari Universitas Dehasen bengkulu yang berupa iklan, personal selling dan publisitas.

Berdasarkan analisis path yang telah dilakukan diketahui bahwa variabel iklan tidak mempengaruhi pilihan rasional mahasiswa Universitas Dehasen Bengkulu dalam hal primary buying motives, ini artinya kegiatan priklanan yang ada dan dilakukan oleh Universitas Dehasen Bengkulu secara berkala tidak berkaitan sama sekali dengan motif mahasiswa dari segi kebutuhan dasarnya. Kebutuhan dasar merupakan kebutuhan yang sudah harus dimiliki oleh mahasiswa bisa karena tuntutan dalam lingkungan mahasiswa atau calon mahasiswa maupun tuntutan kewajiban yang harus dipenuhi oleh mahasiswa sebagai seorang manusia.

Hasil analisis mengungkapkan bahwa iklan mempengaruhi selective buying motives, dan patronage buying 
motives, ini dikarenakan adanya unsur informatif, persuasif, dan reminder yang ada dalam unsur iklan Universitas Dehasen Bengkulu, sehingga mahasiswa mengetahui secara detil apa yang harus diperoleh dan tidak ketika hendak mendaftarkan diri pada Universitas Dehasen, berbagai prosedur dan informasi yang dilakukan secara berkala dalam iklan Universitas Dehasen memberikan peluang bagi mahasiswa untuk berfikir secara realistis dan terbuka mengenai apa saja yang menjadi keuntungan bagi mahasiswa apabila mahasiswa memutuskan untuk berkuliah pada Universitas Dehasen Bengkulu.

Primary buying motives terdiri dari kebutuhan-kebutuhan pokok manusia saja, dan bukan karena faktor lain selain faktor kebutuhan pokok. Pada dasarnya iklan memiliki berbagai konten yang berisi mengenai pesan-pesan persuasif agar seseorang dapat dipengaruhi oleh iklan, akan tetapi pengaruh iklan tidak akan mampu mempengaruhi kebutuhan pokok hidup seseorang.

Selanjutnya mengenai patronage buying motives yang tidak mempengaruhi preferensi calon mahasiswa, merupakan temuan yang mengindikasikan bahwa calon mahasiswa rata-rata mengabaikan pemenuhan faktor tersebut dalam dirinya, patronage buying motives pada dasarnya merupakan sebuah pemikiran rasional dalam diri seseorang dalam memilih sesuatu yang ditinjau dari adanya pelayanan yang baik, lokasi, persediaan, dan kondisi parkir yang baik. dilihat pada kondisi lapangan maka diketahui bahwa lokasi dan persediaan parkir di Universitas Dehasen pada saat ini tidaklah kondusif, akan tetapi calon mahasiswa yang sudah memutuskan untuk melanjutkan untuk melanjutkan pendidikan ke jenjang perguruan tinggi di Universitas Dehasen Bengkulu tidak mempersoalkannya artinya faktor selective buying motives, dan primary buying motives dalam diri calon mahasiswa sudah cukup untuk membentuk preferensi mahasiswa agar memutuskan diri untuk melanjutkan pendidikan ke jenjang pendidikan tinggi di Universitas Dehasen Bengkulu.

\section{PENUTUP}

Berdasarkan hasil penelitian dan pembahasan dapat disimpulkan bahwa Iklan tidak mampu mempengaruhi primary buying motives Mahasiswa Universitas Dehasen Bengkulu karena calon mahasiswa menganggap salah satu kebutuhan pokoknya adalah pendidikan, jadi pada dasarnya mahasiswa yang merasa bahwa pendidikan merupakan kebutuhan pokok tidak akan melihat iklan sebagai acuannya, melainkan dampak dari pemenuhan kebutuhan pendidikan tersebut ini dikarenakan dengan memiliki pendidikan yang layak maka mahasiswa akan memiliki kemampuan di berbagai bidang akademis sehingga mahasiswa akan mendapatkan pekerjaan yang layak dan dari imbalan dari pekerjaan yang layak tersebut kebutuhan pokok mahasiswa selain pendidikan akan mampu terpenuhi dengan optimal. Variabel personal selling dan publisitas mampu mempengaruhi selective buying motives, patronages buying motives, dan primary buying motives, akan tetapi patronage buying motives tidak memiliki pengaruh terhadap preferensi mahasiswa sehingga dapat disimpulkan bahwa personal selling dan publisitas akan mampu mempengaruhi preferensi mahasiswa dengan mempengaruhi selective buying motives dan pimary buying motives terlebih dahulu.

\section{DAFTAR PUSTAKA}

Buku :

Arikunto, S. 2002. Prosedur penelitian, Suatu Pendekatan Praktek. Jakarta:Rineka Cipta 
Buchari, Alma. 2011. Manajemen Pemasaran \& Pemasaran Jasa. Bandung:CV.Alfabeta

Hermawan, Agus. 2012. Komunikasi Pemasaran. Jakarta:Erlangga

Ritonga, Rahman. 2007. Statistika untuk Penelitian Psikologi dan Penelitian. Jakarta: Lembaga Penerbit Fakultas Ekonomi UI.

Ritzer, Georde, Barry Smart. 2015. Hand Book Teori Sosial. Jakarta:Nusa Media

Silalahi, Ulber. 2015. Metode Penelitian Sosial. Bandung:Refika Aditama

Sugiyono. 2010. Metode Penelitian kuantitatif Kualitatif. Bandung : Alfabeta

Surbakti, Ramlan. 1992. Memahami ilmu politik. Jakarta:Gramedia

Vivian, John. 2008. Teori Komunikasi Massa. Jakarta : Kencana
Jurnal :

Indarto, Rossi Prasetya. 2011. Analisis Preferensi Konsumen Terhadap Bundling Kartu GSM dengan Smartphone. Tesis : Universitas Indonesia.

Demir, Muge. 2011. Importance of Ethic, Credibility and Reliability in Online Journalism. Volume 24. European Journal of Social Scince

Website :

Wikipedia. 2016. Daftar negara menurut jumlah penduduk. Diunduh pada tanggal 18 Agustus 2016.

https://id.wikipedia.org/wiki/Daftar negara_menurut_jumlah_penduduk. 